TEME, г. XLIII, бр. 2, април - јун 2019, стр. 475-488

\author{
Оригинални научни рад \\ https://doi.org/10.22190/TEME180305029K \\ Примљено: 5. 3. 2018 \\ Ревидирана верзија: 2. 9. 2018. \\ Одобрено за штампу: 2. 9. 2018.
}

\title{
THE POSSIBILITY OF THE DEVELOPMENT OF BIRD WATCHING AS A SPECIFIC FORM OF TOURISM IN THE DELIBLATO SANDS - CASE STUDY
}

\author{
Živana R. Krejić ${ }^{1 *}$, Snežana Milićević ${ }^{2}$, \\ Katarina Plećić $\hat{c}^{3}$, Dragana Babić ${ }^{4}$ \\ ${ }^{1}$ Economic-trade school Pančevo, Pančevo, Serbia \\ ${ }^{2}$ University of Kragujevac, Faculty of Hotel Management and Tourism, \\ Vrnjci spa, Serbia \\ ${ }^{3}$ Singidunum University, Faculty of Health, Legal and Business Studies, \\ Valjevo, Serbia \\ ${ }^{4}$ University Union, Faculty for Business Studies and Law, Belgrade, Serbia \\ "zkrejic@yahoo.com
}

\begin{abstract}
During 2017, the Society for bird protection in Serbia has organized free trips for domestic tourists in the protected nature reserves in northern Serbia. Their main task was to educate tourists about rare bird species in Serbia and explore the possibility for the development of bird watching, as a specific form of tourism. Since these forms of tourism are not sufficiently developed on Serbian travel market, the main aim of this paper is to examine the motives of tourists who are taking trips. Results of the research should determine the manner in which domestic tourists, in economically underdeveloped countries like Serbia, are related to natural values and whether it is possible that specific forms of tourism become point of interest for domestic tourists and part of the tour operators offer.

The aim of the paper is to present the opinions of a group of 54 tourists who visited The Special Nature Reserve Deliblato sands in June 2017 for the education and observation of rare species of birds. Research has shown that the dominant motives of tourists were related to their need for physical activity, recreation and leisure, rather than observing and photographing rare birds. The results of the survey of the descriptive statistics show that the majority of the respondents believe that the observation of birds and sustainable tourism in the Nature Reserve of the Deliblato sands will only experience its development.

Research results can be useful to business entities in tourism with the aim of forming a tourist offer for domestic and foreign tourists as well as individuals, with the aim of developing awareness of the importance and importance of protected nature reserves and their preservation in the future. This is the not first study, but one of the pioneer research to examine the motives of traveling by domestic tourists in terms of specific forms of tourism development in Serbia.
\end{abstract}

Key words: tourism, tourists, bird watching, the Deliblato sands, special interest tourism. 


\title{
МОГУЋНОСТИ РАЗВОЈА ПОСМАТРАњА ПТИЦА КАО СПЕЦИФИЧНОГ ОБЛИКА ТУРИЗМА У ДЕЛИБЛАТСКОЈ ПЕШЧАРИ - СТУДИЈА СЛУЧАЈА
}

\begin{abstract}
Апстракт
Током 2017. године Друштво за заштиту птица у Србији организовало је бесплатне излете за домаће туристе у заштићеним природним резерватима на северу Србије. Њихов главни задатак био је едукација туриста о ретким врстама птица у Србији и истраживање могућности посматрања птица као специфичног облика туризма. Пошто ови облици туризма нису довољно развијени на српском туристичком тржишту, главни циљ рада је да испита мотиве туриста који их опредељују ка оваквим облицима путовања. Резултати истраживања требало би да одреде начин на који су домаћи туристи у економски неразвијеним земљама, као што је Србија, повезани са природним вредностима и да ли је могуће да специфични облици туризма постану интересантни за домаће туристе и креаторе туристичке понуде.

Циљ рада је и да представи ставове групе од 54 туриста који су у јуну 2017. посетили Специјални резерват природе Делиблатска пешчара ради едукације и посматрања ретких врста птица. Истраживање је показало да су доминантни мотиви туриста везани за путовање у вези са физичком активношћу, рекреацијом и слободним временом, уместо посматрања и фотографисања ретких птица. Резултати истраживања дескрипитивне статистике показују да највећи број испитаника сматра да ће посматрање птица и одрживи туризам у резервату природе Делиблатска прешчара тек доживети свој развој.

Резултати истраживања могу бити корисни привредним субјектима у туризму, са циљем формирања туристичке понуде за домаће и стране туристе, али и појединцима, са циљем развоја свести о значају и важности заштићених резервата природе и њиховог очувања у будућности. Ово није прва студија, али је пионирско истраживање које испитује мотиве путовања домаћих туриста у погледу могућности развоја специфичних облика туризма у Србији.
\end{abstract}

Кључне речи: туризам, туристи, посматрање птица, Делиблатска пешчара, специфични облици туризма, Војводина.

\section{INTRODUCTION}

The increased level of tourist education has brought about the needs for a different tourist product, which implies numerous contents, including outdoor activities and an awareness of ecological problems (Šušić, Bratić, \& Milovanović, 2016). The ability to promote sustainable tourism and preserve its competitive advantage is greatly influenced by the quality of the environment, the preservation of attractive natural and cultural heritage, other values, goods and resources (Angelkova, Koteski, \& Jakovlev, 2012).

Special interest tourism includes different forms of travel with a special interest. Some of the most important ones are adventurous, rural, cultural, ecological (bird watching), medical tourism (Kruja \& Gjyrezi, 
2011). New forms of tourism and tourist's special demand are increasing in recent decades. Independent journeys tend to differentiate from mass tourism and tend to be morally and ethically acceptable. That is why some authors claim that this could be a chance for the Third World Countries to overcome underdevelopment and to offer new forms of tourism related primarily to ecology (Mowforth \& Munt, 2015). The increase of pollution, noise and everyday life pressure have contributed to increasing number of tourists in preserved nature (Muhi, 2009). Birdwatching is a relatively new tourist attraction, it appeared in tourism literature 25-30 years ago (Applegate \& Clark, 1987; Kellert, 1985; Kerlinger, 1992).

Birdwatching represents the activities of spotting, observing and listening to birds in their natural habitats, with the main goals of recreation, respecting animals, education and photography (Vas, 2017). Nowadays this form of ecotourism has developed into free activity and is considered as one of the nature based most popular and fastest growing tourist activities in the world (Carvel, 2013). Some authors estimated that in period from 2005 to 2009, nearly 20 million Americans traveled for bird watching, with average stay of around 14 days (Robinson, 2012).

Protected natural resources are especially interesting to entrepreneurs who are seeking for such a way of vacation and living that is oriented to traditional values, but also to sustainable tourism. American tourists showed a great interest in wildlife. About $20 \%$ of Americans declared themselves as birdwatchers, they spend about $\$ 50$ billion annually on this type of tourism (Areas, Filippelli \& Jones 2014; Carver, 2011).

The northern parts of Serbia abound in wetlands and areas marked as protected natural resources, which can provide pleasant and meaningful experiences to excursionists and tourists, as birdwatchers in Vojvodina. One of the most important nature reserves in Serbia marked as the largest oasis of sand, forest and wetland vegetation in Pannonian Basin is the Special Nature Reserve Deliblato sands. Over 900 species of plants, of which many are under protection, as well as a large number of the animal world, are of particular importance to this reserve. This is also very important landscape for birds. More precisely, Labudovo okno art of Danube sandstone, declared for the Ramsar and Emerald area (Kadović \& others, 2016).

In June 2017, Bird protection and study society of Serbia organized free trips for domestic tourists from major Serbian cities in order to educate them of rare and protected species of birds in Deliblato sands. The main goal of this paper is to present the attitudes of domestic tourists who visited this protected area of nature for the first time. Endpoints of this case study are examining tourist's opinions regarding the possibility of birdwatching development as so far unknown form of tourism. 


\section{LITERATURE REVIEW}

A review of the literature about bird watching development points to the fact that a lot of research has been done on this subject. Birdwatching is the main component of wildlife tourism and one of the most growing forms of entertainment in tourism in the Western world. Tourists who are practicing birdwatching are generally well educated and relatively wealthy (Jones \& Buckley, 2001). Birdwatching has contributed to the integration of research about their protection, conservation and further socio-economic development.

Interest in this form of tourism in China begins around 1990 thanks to foreign tourists. In the meantime, associations for the protection of birds have been established, which positively affect the increase in the number of tourists and visitors (Ma, Cheng, Wang, 2012). It is estimated that in United Kingdom, there were 72 million visits to nature, and most of them include birdwatching. Bird watching is also important from the point of generating economic income and employment at local and national level (Carver, 2009). The role of tourism in local economic development is crucial (Obradović-Matijašević, Lukavac \& Miletić, 2017).

Birdwatching is an act of birds observation and identification in their native habitat. This is one of the greatest revenues from ecotourism, as it is about the largest individual groups of eco-tourists who are very educated, with above the average income (Cordell \& Herbert, 2002). Their visits to destinations for birdwatching make significant income from tourism and provide significant financial revenue for protected natural areas rich in endemic species (Hill, Cable \& Scott, 2010). They are preferred tourists not only because of their nature based activities, but because they are ready to pay the higher travel costs in order to watch birds (Cheung \& Jim, 2014).

Birdwatching in literature is also listed as a fun, leisure activity, especially in capitalist economies as response to rapid urbanization and reduction of green spaces in many urban areas (Giglio, Luiz \& Schiavetti, 2015).

On the other hand, when it comes to domestic authors, only a few of them chose this specific, birdwatching topic for their research. Previous works have been based on the potentials for birdwatching development, mainly in rural areas. Ristić and associates believe it is necessary to design tours for birdwatching (Ristić, Vujičić \& Leković, 2016), as well as Jegdic and associates (Jegdić, Škrbić \& Milošević, 2017) which point out certain areas in Vojvodina as an eco-rural destination, such as the Upper Danube River, considering birdwatching and photo safaries as main attractions in protected natural areas. Muhi (2009a) stresses that it is important to deal with development of this form of tourism because of small investments it requires, and profit, while Milićević and Petrović (2017) also point out that Serbia has the resources to develop bird watching. The domestic authors agreed that areas of preserved nature are the chance for the birdwatching 
development in the areas of Fruška Gora National Park (Medić, Gagić \& Jovičić, 2012), Special Nature Reserve Deliblato sands (Krejić \& Plećić, 2014), in villages at the border crossings between the two countries (Angelkova \& others, 2014), in Rača area-as a rural tourism destination (Milićević, Podovac, \& Čavlin 2015), in Vrbas municipality and close to Danube-Tisa-Danube canal (Mrkša \& Gajić, 2014).

However, the first proper birdwatching activities for domestic tourists were undertaken by Bird Protection and Study Society of Serbia. It was an opportunity to examine the attitude of domestic tourists and to conduct first research about development of this type of tourism in area of Special Nature Reserve Deliblato sands. Hence, the main hypothesis that has come to this paper is H1: Domestic tourists consider that birdwatching development is possible as a form of tourism in Special Nature Reserve Deliblato sands. Auxiliary hypothesis of paper is H2: Most of domestic tourists are highly educated people with sustainable tourism and nature conservation awareness.

\section{METHODOLOGY OF RESEARCH}

The Special Nature Reserve Deliblato sands is located in southern Banat, situated between the river Danube and the southwestern slopes of the Carpathian Mountains. The unique mosaic of ecosystems contains typical species of flora and fauna, among which many are rare and significant according to international criteria. The rich flora with over 900 species, subspecies and varieties abounds in rarities, relics, endemics and sub endemics.

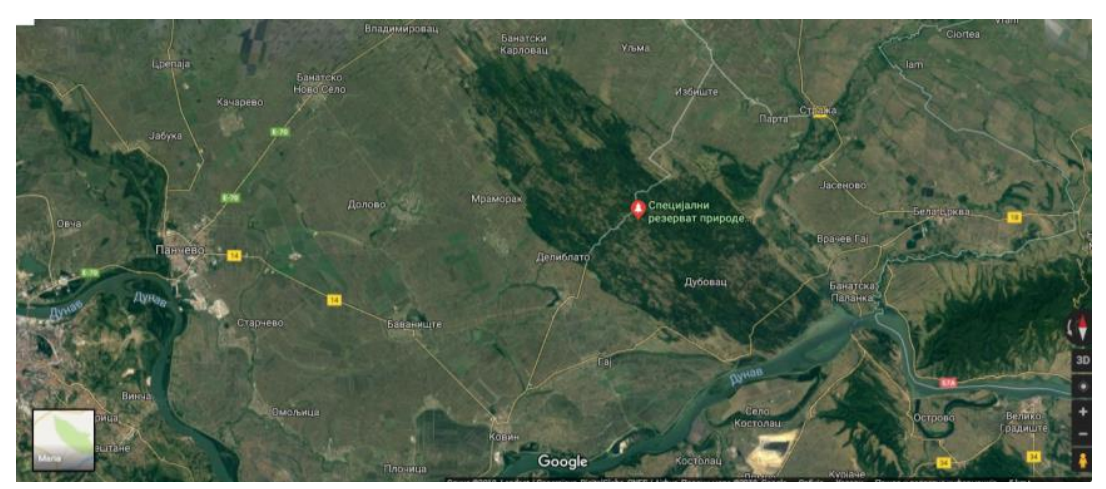

Map 1. The Special Nature Reserve Deliblato sands Source: maps.google.com

This area protected natural resources also include a part of the Danube course, its marshes and islets. Waters abounding in fish and a number of hatcheries represent an important gathering-point and mass 
wintering grounds of waterfowl. This is why the Deliblato sands was designated as an Important Bird Area in 1989 (IBA). It is also the nesting place of many rare species, such as: little egret, yellow heron, ibis and sand-martin. Small cormorant-a highly endangered species in Serbia-has its only safe nesting place here (Popović, Smiljanić, \& Matić, 2012).

The main hypothesis from which the work was begun is the examination of the possibility of development of the birdwatching species in the Special Nature Reserve the Deliblato sands. Auxiliary hypotheses in work are: Ho1 Tourists who show interest in specific forms of tourism are highly educated and understand the importance of sustainable tourism development, $\mathrm{Ho} 2$ Travel motives are related to the observation and photographing of protected species of birds.

The hypotheses were examined on a sample of 54 visitors who had been in the Deliblato Sands Nature Reserve in June 2017 organization by the Society for birds protection in Serbia. This study used questionnaires methods for data collecting in order to analyze domestic tourists attitudes about the birdwatching development possibilities in Deliblato sands. The data were obtained on a trip through visitors survey than analyzed using descriptive method and inferential statistics. The obtained results have been analyzed and used and can be implemented in certain conclusions on the future tourism development directions in Vojvodina, both for foreign and domestic tourists, as well as for future development directions of birdwatching as a specific form of tourism. The first phase of the research was conducted at area of Deliblato sands regardinding to respondents data collecting, while the second phase concerned ordering and obtained results analysing, as well as making conclusions. The questionnaire which made 10 questions, as research instrument, was forwarded to all the present tourists who fully expressed their opinion. The database was created in MS Excell, while the data was tested in IBM SPSS Statistics v.17- software package for statistical analysis.

Descriptive methods were used to describe the population surveyed: frequency distributions (nominal and percent), average values, median, standard deviation, ranking, minimum and maximum values. The data processing results are displayed graphically using dispersion diagrams, columns, pie charts and tables.

\section{RESULTS AND DISCUSSION}

With regard to the whole sample of 54 respondents, the survey questionnaire was answered by 30 women and 24 men, i.e., $55.6 \%$ of women and $44.4 \%$ of men. 


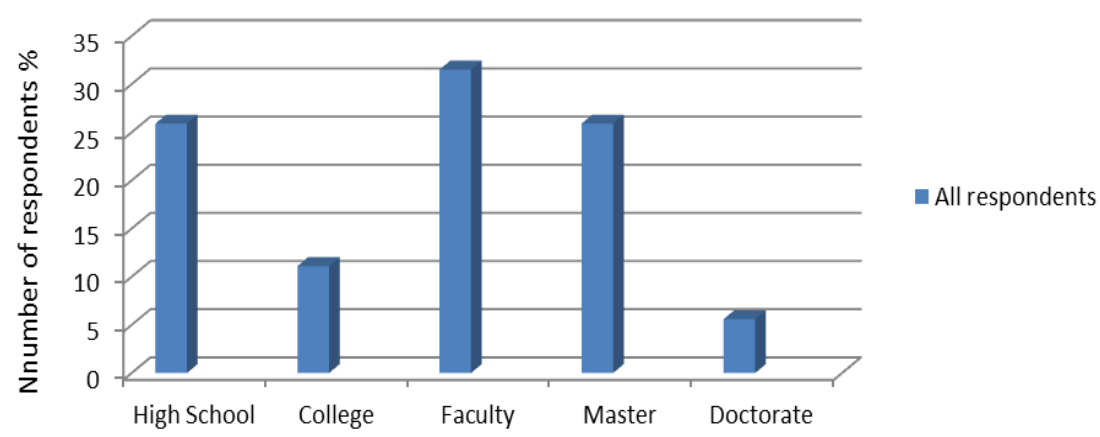

Figure 1. Distribution of respondents according to professional qualifications Source: authors.

When it comes to the respondents qualifications structure, the highest number of respondents has faculty degree $-31.5 \%$ of them, while secondary school degree and master degree is owned by the same number of respondents, more precisely $25.9 \%$ of them. There are $11.1 \%$ of respondents with high school diploma and while $5.6 \%$ of them with $\mathrm{PhD}$ degree. The obtained data support the statement of the authors pointing out that the most of bird watchers are with high education level (Sekercioglu, 2002; Buijs, Pedroli \& Luginbuhl, 2006; Cakici \& Harman, 2007).

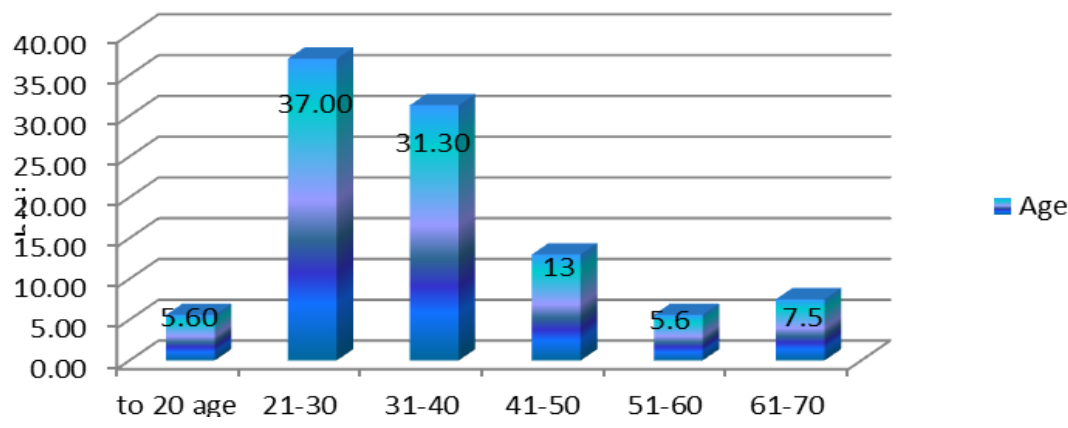

Figure 2. Distribution of respondents by age groups Source: authors

Figure 2 shows that majority of respondents was between 21-30 years $-37 \%$ of them, followed by respondents from 31-40 years who made $31.30 \%$, ones from $41-50$ years made $13 \%$ of respondents, while slightly older tourists in range of $61-70$ years made $7.5 \%$ the respondents. The smallest respondents group aged 51-60 years old and that's 5.6\%, as well as those who were under 20 years. 


\section{Employment}

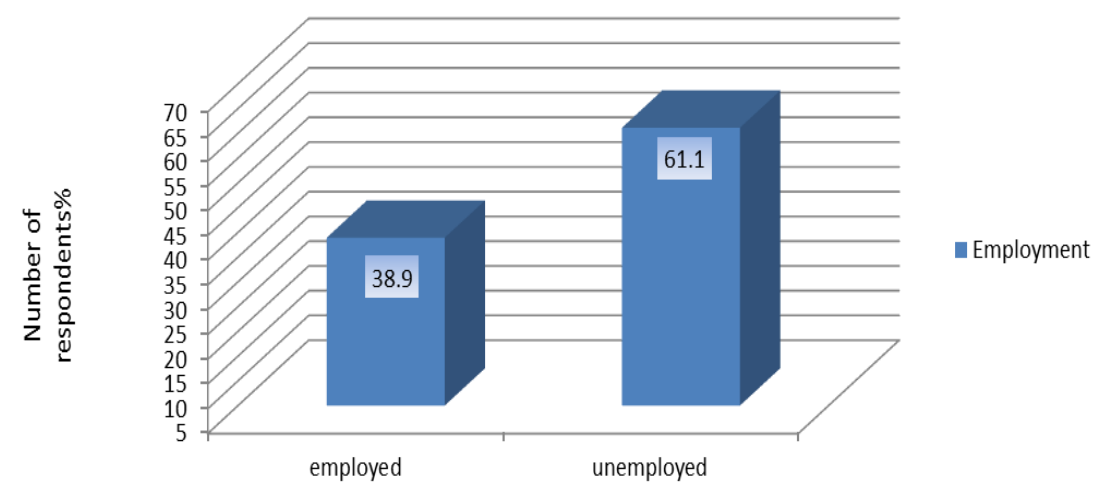

Figure 3. Distribution of respondents according to employment Source: authors.

Figure 3 shows that most visitors were unemployed, 33 of them, i.e., $61.1 \%$, while the number of employees was 21 , i.e., $38.9 \%$.
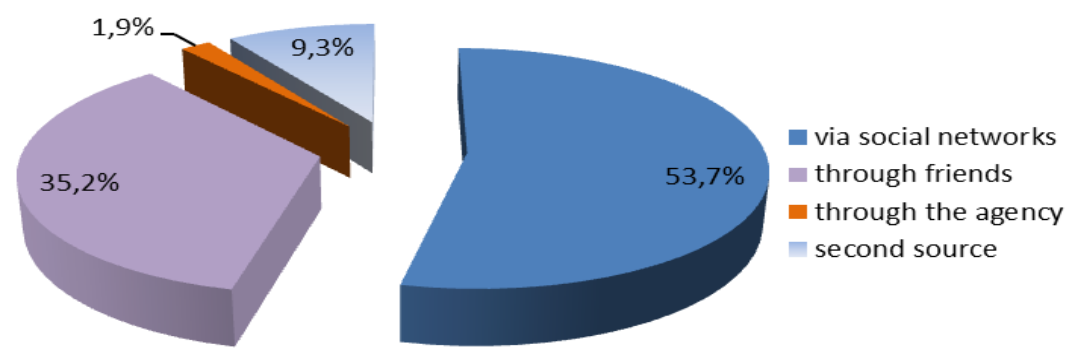

Source: authors.

Figure 4. Distribution of respondents according to the way they were informed about the trip

Figure 4 shows the manner of how the respondents were informed about the trip. Most of them, $53.7 \%$, found out about this trip via the internet (a total of 29 respondents), which is not surprising given that it is a relatively young and highly educated population. $35.2 \%$ of them or 19 respondents, have heard from friends about this wirdbatching trip, while $11.2 \%$ found out otherwise.

As the main reasons for the trip, majority of respondents stated relaxation, physical activity and walking, recreation and raising awareness about nature conservation. 


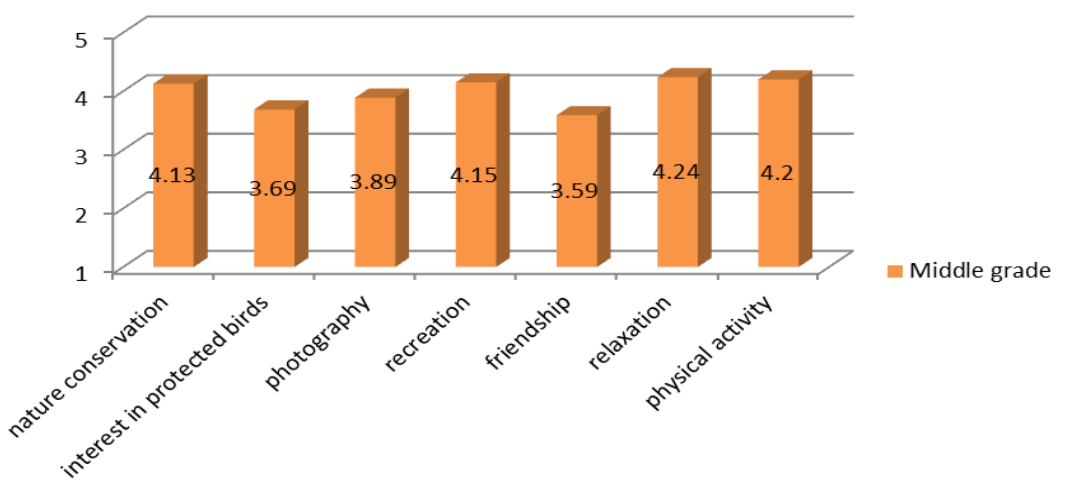

Figure 5. The main reasons for trip Source: authors.

Almost identical motifs for the birdwatchers arrivals were recorded in studies conducted by foreign authors nearly 20 years ago in regions of America and Australia (Scott \& others, 1999). Also in Great Britain, this types of tours have been organizing because of their relaxing character, with main motif for tourists-observing wild animals (Curtin, 2010).

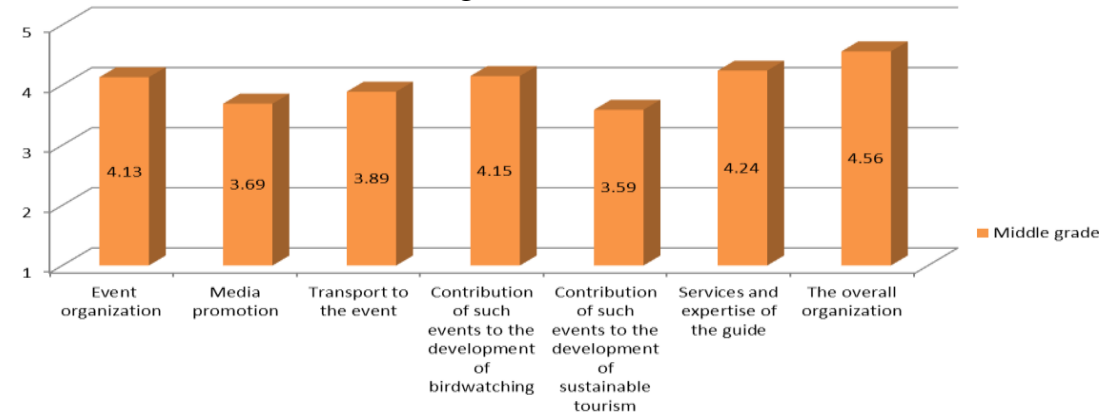

Figure 6. Level of satisfaction with trip organization Source: authors

When the overall trip organization is considering, the respondents rated efforts of volunteers of Bird Protection and Study Society of Serbia on a scale to $1-5$, which resulted with a very high average result of 4.56. Top rated segments were guides services and expertise at the site.

Most of the respondents expressed their opinion that contibution of such kinds of trips is the chance for future birdwatching development. Certain responses and high ratings should be taken with reserve, considering this birdwatching trip was free. Related to this, Figure 7 shows the readiness of the respondents to allocate money for the conducted trip wich, in addition to organization, included transportation and professional guidance services. Majority of respondents is ready to pay for such a trip, 
$53.7 \%$ of them, while the other $44.4 \%$ answered that it depends on the price, which is understandable, given the fact that $61.1 \%$ of the respondents were unemployed (Figure 3).
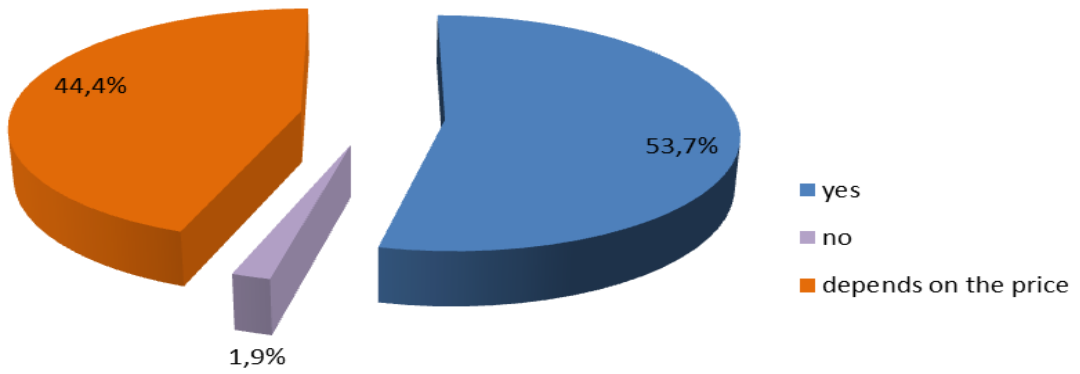

Figure 7. The results of the questios whether respondents were willing to pay for such trip
Source: authors.

Figure 8 shows the results of the question regarding the readiness and payment amount for the trip. Regardless of the high ratings they gave to the overall organization, guide, and other parts of the excursion (Figure 6), majority of respondents would be willing to allocate between RSD 800 and 1000, or an average of EUR 7.5 for this trip. Then there is a group of tourists willing to pay from RSD 500-800, or about EUR 5, 27.8\% of them. A total of $25.8 \%$ of respondents would be willing to pay RSD 300-500, i.e. about EUR 3.5 , while the smallest group of respondents is ready to pay RSD 1200-1500, i.e. around EUR12. Such results can be explained by the fact that the majority of respondents were unemployed, and that Serbia is small and underdeveloped country.

On the other hand, these results do not match with research papers from abroad, which show that birdwatchers are prepared to pay high prices for such trips.

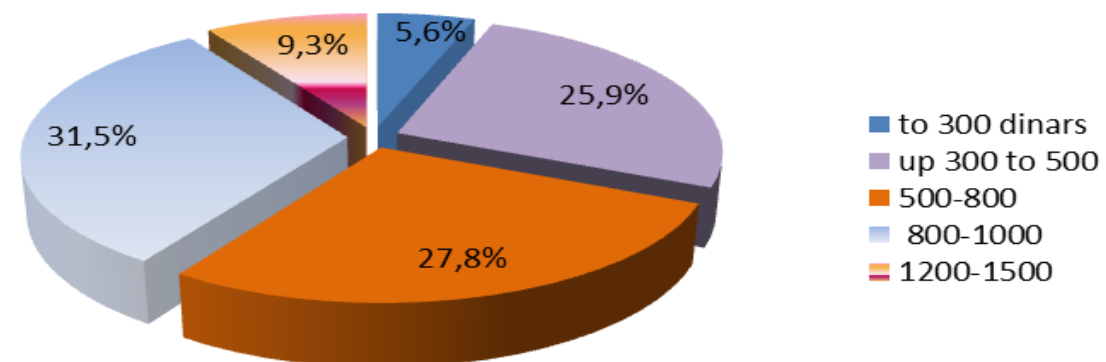

Figure 8 . The results of the question whether respondents were willing to pay for trip Source: authors. 


\section{CONCLUSION}

Considering obtained results of research within the case study, we are confirming the main hypothesis of this paper-birdwatching development as a form of tourism in Special Nature Reserve the Deliblato sands. We also accept the first auxiliary hypothesis in the work, that tourists who visited the nature reserve are highly educated and have awareness of sustainable development. However, we dismiss another auxiliary hypothesis because the most common motives for such travels are recreation, recreation and stay in nature, and less photographing and observation of protected bird species. As a reason we can mention small population incomes, insufficient knowledge of protected birds, and lack of quality techniques for photographing.

If one takes into account that none of the marketing activities were present, it can be concluded that demand for the education of domestic tourists, in terms of new forms of tourism, is outstanding.

The main motives for domestic tourists departure to until then unknown birdwatching trip, observation, were relaxation, recreation and spending time in a clean and healthy environment, such as the Special Nature Reserve of the Deliblato sands.

Developing countries like Serbia have highly educated tourists and excursionists willing to, despite small incomes, spend money for educational excursions. It is also a group of people who emphasize the importance of sustainable tourism, but who is willing to contribute to the preservation of nature and its values by volunteer work. Therefore, this research can be significant for future projects and manners of financing such excursions for the local population of citizents, associations and tourist organizations, chambers of commerce, but also as a unique contribution to development and preservation of nature and its values in developing countries. Birdwatching as a form of tourism can positively reflect on the increase in the activity of domestic tourists in nature, which in future can positively reflect to overall health status of the inhabitants of one country.

Although this form of tourism in Serbia is at the beginnings, it is assumed that increase demand for birdwatching will be felt in the years to come. The polluted environment, the inability of a large number of Serbian citizens to travel to other destinations, will direct them to spend their free time in nature. Wildlife, search for adventures, visiting bird habitat, feeding wild animals are just some of the activities that can be practiced in the Special Nature Reserve of Deliblato sand. 


\section{REFERENCES}

Angelkova T., Koteski C. \& Jakovlev Z. (2012). Sustainability and Competitiveness of Tourism. Procedia - Social and Behavioral Sciences, Vol. 44, pp. 221-227.

Angelkova T., Cvejić R., \& Madžar, J. (2014). Sustainable rural tourism in the revitalization of villages in the border region between Macedonia and Serbia. Ecologica. Vol. 21, No.73, pp.18-25.

Applegate J.E., Clark K.E (1987). Satisfaction levels of birdwatchers: An observation on, the consumptive-non consumptive continuum. Leisure Sciences: An Interdisciplinary Journal, Vol.9, pp. 129-134.

Ares A., Filippelli S. \& Hallowell R. (2014). Improving Bird Watching at the Ohio State University Wetlands: Columbus. The Ohio State University, Ohio.

Buijs, A.E., Pedroli B. \& Luginbuhl Y. (2006). From hiking through farmland to farming in a leisure landscape: changing social perceptions of the European landscape. Landscape Ecology, Vol. 21, pp. 375-389.

Cakici AS., Harman S., (2007). Importance of destination attributes attributes affecting destination choice of affecting destination choice of Turkish birdwatchers. Journal of Commerce \& Tourism Education, No. 1, pp.131-145.

Carver, E. (2009). Birding in the United States: A demographic and economic analysis. Report 2006-4. Arlington VA: US Fish and Wildlife Service, Division of Economics.

Carver, E. (2011). Birding in the United States: A demographic and economic analysis. U.S. Fish and Wildlife Service Report. Retrieved December 20, 2017.

Carver, E. (2013). Birding in the United States: A demographic and economic analysis addendum to the 2011 national survey of fishing, hunting, and wildlife-associated recreation report. Fish and Wildlife Service, Arlington, Washington.

Cordell, H. K., Herbert, N. G. (2002). The popularity of birding is still growing. Yangtze. Frontier in. Ecology Environment, Vol. 4, pp. 369-377.

Cheung, L. T. O., \& Jim, C. (2014). Expectations and willingness-to-pay for ecotourism services in Hong Kong's conservation areas. International Journal of Sustainable Development \& World Ecology, Vol. 21, No.2, pp. 149-159.

Giglio, V., Luiz, O., \& Schiavetti, A. (2015). Recreational Diver Behavior and Contacts with Benthic Organisms in the Abrolhos National Marine Park, Brazil. Environmental Management, Vol.57, pp. 637-648.

https://maps.google.com, Retrieved 13.8.2018.

Hill, S. G., Cable, T. T., \& Scott, D. (2010). Wildlife-based recreation as economic windfall: a rhetorical analysis of public discourse on birding. Applied Environmental Education and Communication, Vol. 9, No.4, pp. 224-232.

Jegdić, V., Škrbić I., Milošević, S. (2017). Modeli razvoja preduzetništva u destinacijama ruralnog turizma u Srbiji [prevod na engleski]. Ekonomika poljoprivrede. Vol. 64, No. 1, pp. 221-237.

Jones N.D, Buckley R. (2001). Birdwatching tourism in Australia. (Wildlife Tourism Research Report Series No. 10). Gold Coast, Queensland: Cooperative Research Centre for Sustainable Tourism.

Kadović R., Bohajar Y.A.M.\& Perović V. (2016). Land Sensitivity Analysis of Degradation using MEDALUS model: Case Study of Deliblato Sands, Serbia. Archives of Environmental Protection, Vol. 42, No. 4 pp. 114-124.

Kellert, S.R. (1985). Bird-watching in American society. Leisure Sciences: An Interdisciplinary Journal, Vol. 7, No.3, pp. 343-360. 
Kerlinger, P. (1992). Birding economics and birder demographics studies as conservation tools. Cape May Bird Observatory, Cape May Point, NJ: New Jersey Audubon.

Krejić, Ž., Plećić, K. (2014). Options the Deliblato sand for the development of specific forms of tourism, International scientific journal: Horizons, Vol. 13, pp.317-324.

Kruja D., Gjyrezi A. (2011). The Special Interest Tourism Development and the Small Regions. Turizam: Vol 15, No. 2, pp.77-89.

Ma Z., Cheng Y. \& Wang J. (2013). The rapid development of birdwatching in mainland China: a new force for bird study and conservation. Bird Conservation International, Vol. 23, pp. 259-269.

Medić, S., Gagić S. \& Jovičić A.(2012). Possibilities for Improvement of Rural Tourism in Fruška Gora Journal of Settlements and Spatial Planning, Special Issue, vol. 1, pp. 167-175.

Milićević, S., Podovac M.\& Čavlin M. (2015). Resources for development the Rača Municipality as a rural tourism destination. Economics of Agriculture, 62(3), pp. 751-765

Milićević, S., Petrović, J. (2017), Tourist products in the function of improving competitiveness of Serbia as a tourist destination, 2nd International Scientific Conference "Tourism in Function of Development of the Republic of Serbia Tourism product as a factor of competitiveness of the Serbian economy and experiences of other countries", eds: Cvijanović, D., Ružić, P., \& Andreeski, C., University of Kragujevac - Faculty of Hotel Management and Tourism in Vrnjačka Banja, Serbia, Vrnjačka Banja, 1-3 June, 2017, Thematic Proceedings I, pp. 167-183

Mowforth M., Munt, I. (2015). Tourism and Sustainability: New Tourism in the Third World. Routledge, London.

Muhi, B. (2009). Primena marketinga u razvoju ekološkog turizma Vojvodine sa posebnim osvrtom na birdwatching [prevod na engleski]. Zbornik naučnog skupa 2: Savremene tendencije u turizmu, hotelijerstvu i gastronomiji, pp. 8790. Univerzitet u Novom Sadu, Prirodno-matematički fakultet, Departman za geografiju, turizam i hotelijerstvo.

Mrkša, M., Gajić, T. (2014). Opportunities for sustainable development of rural tourism in the Municipality of Vrbas. Economics of Agriculture, Vol. 1, pp.163-175.

Natural England (2010). Monitor of engagement with the natural environment: The national survey on people and the natural environment. Annual report from the 2009-10 Survey. Peterborough, UK: Natural England. (Natural England Commissioned Report NECR049).

Obradović-Matijašević J., Lukavac J., \& Miletić, Lj. (2017). The Impact of the Consumption of Hazardous Chemicals on the Development of Agrotourism in Serbia. Industrija, Vol.45, No.3, pp. 167-182.

Popović, Z. Smiljanić, M., \& Matić, R. (2012). Phytotherapeutical plants from the Deliblato sands (Serbia): traditional pharmacopoeia and implications for conservation. Indian Journal of Traditional Knowledge, Vol. 11 (3), pp.358-400.

Ristić L., Vujičić M. \& Leković M. (2016). Turizam kao faktor održivog razvoja ruralnih područja Rudničke Morave. Ekonomika poljoprivrede, Vol. 2, pp. 665-680.

Robinson H.R. (2012). Building a framework for sustainable tourism in key biodiversity, areas in the Dominican Republic and Jamaica: The Caribbean birding trail. Master of Science thesis in conservation biology and sustainable development. University of Wisconsin-Madison, Madison. 
Sekercioglu, C.H. (2002). Impacts of birdwatching on human and avian communities. Environmental conservation, Vol 29, No. 3, pp. 282-289.

Scott, D., Baker, M.Z., Kim, Ch. (1999). Motivations and Commitments among Participants in the Great Texas Birding Classic. Human Dimensions of Wildlife, Vol.4, No.1, pp. 50-67.

Šušić, V., Bratić, M. \& Milovanović, M. (2016). Demographic and socioeconomic charachteristics and motives of the visitors to the tourist manifestation Nisville Jazz Festival. Teme, Vol. 15, No.1, pp.123-137.

Vas K. (2015). Birding blogs as indicators of birdwatcher characteristics and trip preferences: Implications for birding destination planning and development. Journal of Destination Marketing \& Management, Vol. 6, No. 1, pp. 33-45.

\title{
МОГУЋНОСТИ РАЗВОЈА ПОСМАТРАҢА ПТИЦА КАО СПЕЦИФИЧНОГ ОБЛИКА ТУРИЗМА У ДЕЛИБЛАТСКОЈ ПЕШЧАРИ - СТУДИЈА СЛУЧАЈА
}

\author{
Живана Р. Крејић ${ }^{1}$, Снежана Милићевић ${ }^{2}$, \\ Катарина Плећић ${ }^{3}$, Драгана Бабић ${ }^{4}$ \\ ${ }^{1}$ Економско-трговинска школа Панчево, Панчево, Србија \\ ${ }^{2}$ Универзитет у Крагујевцу, Факултет за хотелијерство и туризам, \\ Врњачка Бања, Србија \\ ${ }^{3}$ Универзитет Сингидунум, Факултет здравстевних и пословних студија, \\ Ваљево, Србија

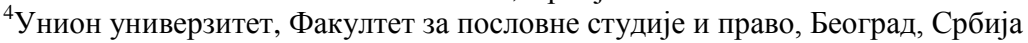

\section{Резиме}

Главни мотиви домаћих туриста за одлазак на до тада први излет посвећен посматрању птица био је у вези са рекреацијом и дружењем у чистом и здравом окружењу, као што је Специјални резерват природе Делиблатска пешчара.

Земље у развоју, попут Србије, имају високообразоване туристе и екскурзионисте који су спремни, упркос малим приходима, да потроше новац на едукативне излете. То је такође група људи који наглашавају важност одрживог туризма, али која је спремна да волонтерским радом допринесе очувању природе и њеним вредностима. Резултати истраживања могу бити значајни за будуће пројекте и начине финансирања излета за локално становништво, удружења грађана и туристичких организација, привредних комора, али и као јединствен допринос развоју и очувању природе и њених вредности у земљама у развоју.

Посматрање птица као облик туризма може се позитивно одразити на укупно здравствено стање становника једне земље. Иако овај облик туризма у Србији тек доживљава своје зачетке, претпоставља се да ће пораст тражње за излетима везаним за посматрање птица бити израженији у годинама које долазе. 